\title{
Range extension and reproduction of the barnacle Balanus perforatus in the eastern English Channel
}

\author{
R.J.H. Herbert*\$, S.J. Hawkins ${ }^{\dagger}$, M. Sheader ${ }^{\ddagger}$ and A.J. Southward ${ }^{\dagger}$ \\ *Medina Valley Centre, Dodnor Lane, Newport, Isle of Wight, PO30 5TE. \\ ${ }^{\dagger}$ Marine Biological Association, The Laboratory, Citadel Hill, Plymouth, PL1 2PB.

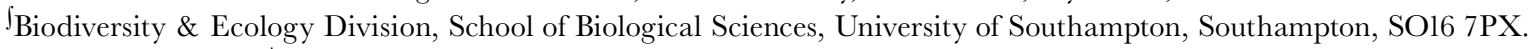 \\ ${ }^{\ddagger}$ SOES, University of Southampton, European Way, Southampton, SO14 3ZH. \\ ${ }^{\S}$ Corresponding author, e-mail: rjhh@islewight.freeserve.co.uk
}

The distribution of the warm-water barnacle, Balanus perforatus, was surveyed along the south coast of England and the north-east coast of France between 1993 and 2001, repeating work carried out between the 1940s and 1960s. The species has recovered from catastrophic mortality during the severe winter of 1962-1963 and was found over $120 \mathrm{~km}$ (UK) and $190 \mathrm{~km}$ (France) east of previous records on both sides of the Channel. The presence of the species in the eastern Channel refutes suggestions in the 1950s that larvae, and hence adults, would not be found east of the Isle of Wight because of reproductive sterility close to the limits of distribution. Brooding of specimens translocated to Bembridge, Isle of Wight, commenced in May, earlier than previously observed in British waters, and continued until September. The stage of embryo development at Bembridge in mid-August was comparable to that of the large population at Lyme Regis, Dorset $100 \mathrm{~km}$ further west. However the size of brood per standard body weight was greater at Lyme Regis. Factors influencing the rate of colonization and further geographic range extension of the species as a possible result of climate change, are discussed.

\section{INTRODUCTION}

Balanus perforatus Bruguière is one of the larger barnacles of European coasts. It usually occurs in the lower half of the littoral zone and may extend into the sublittoral. It is found in variable density on a wide range of hard substrata along wave-beaten shores and in ria-type estuaries (Norris \& Crisp, 1953; Lewis, 1964). It is a southern species, occurring in the Mediterranean and along the eastern Atlantic seaboard from south-west Wales to West Africa, but has not been found in Ireland (Lochhead, 1936; Crisp \& Southward, 1953). Earlier surveys in the English Channel reported the species as common in south-west England and along the coast of Brittany, with eastern limits approximately mid-Channel in the vicinity of the Isle of Wight on the English side, and Cherbourg on the French coast (Fischer-Piette, 1936; Crisp \& Southward, 1958; Lewis, 1964; Stubbings \& Houghton, 1964). There are early records of the species on piers at Blankenberge and Oostende, Belgium (Pelseneer, 1882) and in 1982 it was found at Dunkirk on mussel ropes (Davoult et al, 1993). The species is regularly found on floating objects washed ashore in the southern North Sea and between 1996-1998, four specimens were found fouling the undersides of buoys off the Belgian coast (Kerckhof \& Cattrijsse, 2001). The status of specimens collected from buoys off the Dutch coast and referred to as Balanus perforatus (Buizer, 1978) is confused (Kerckhof \& Cattrijsse, 2001).

Little has been published on the ecology and reproduction of $B$. perforatus. Field studies are difficult as the animals often occur in cryptic habitats such as crevices and beneath overhangs. Norris \& Crisp (1953) found fertilized egg masses in the mantle cavity between midJune and August at Torbay, Devon. Egg development was rapid and nauplii were liberated into the plankton in late June with settlement commencing in late July and continuing through August and into September. On the coast of north Devon, brooding commenced slightly later. These authors found that animals in exposed locations close to their distributional limits on the Welsh coast were small and sterile and speculated that larvae should not be present in plankton hauls taken north of Aberystwyth on the Welsh coast, in the North Sea or in the English Channel east of the Isle of Wight. The most probable factor setting the northern and eastern geographic limits of southern species is sea and air temperature acting indirectly via reproduction and occasionally directly during extreme weather. On the south coast of England, the cold winter of 1962-1963 caused considerable mortality of intertidal fauna. Onshore winds from the south-east accentuated the effect, particularly along the Isle of Wight where in April 1963 B. perforatus were observed not to have survived. In contrast, the opposite coasts of the Channel, where the same winds were offshore, suffered less (Crisp, 1964; A.J. Southward, personal observation). Thus intolerance of low winter temperatures by adult $B$. perforatus has set geographic limits in the recent past. Yet it is also likely that a shorter breeding season close to the northern and eastern limits might limit fecundity, larval supply and therefore recruitment at the edge of the range.

With the possibility in the 1990s that recent warm summers and mild winters may have increased fecundity 
and adult survival, the species distribution along the central south coast of England and north-east France was re-surveyed to compare with baseline surveys from the 1940 s and 1950s. Field experiments were conducted on the Isle of Wight to determine whether gonad and egg development was possible at the geographic limits compared to a population further west and to estimate any differences in brood size and fecundity.

\section{MATERIALS AND METHODS}

\section{Site survey}

The south coast of England between Torbay in south Devon and Eastbourne in Sussex was surveyed between July 1993 and September 1994. Particular attention was directed towards crevices and overhangs in the lower intertidal. When densities were quantifiable, a $400 \mathrm{~cm}^{2}$ quadrat was placed randomly to assess density. Abundance was converted to a semi-quantitative scale (Table 1) devised by Crisp \& Southward (1958). Shores in Devon, Dorset and the Isle of Wight were surveyed annually thereafter until October 2000. Further visits to sites along the Sussex coast were made in September 1997 and again in September 2001 when shores in Kent as far as North Foreland were also surveyed. Surveys on the French coast between the Contentin Peninsula and Calais were carried out in October 2000 and September 2001. Field measurements of the basal diameter along the rostro-carinal axis were made at selected sites.

\section{Reproduction}

\section{Translocation experiments}

Natural populations close to geographic limits were not large enough to determine if animals undergo normal gonad and egg development. Animals from Lyme Regis (a site in Dorset, west of Portland Bill on the south coast of England where the species was abundant and observed to recruit frequently) were translocated to Bembridge on the Isle of Wight. In November 1994, small rocks and cobbles, densely colonized by Balanus perforatus, were removed from low water neap (LWN) on Broad Ledge at Lyme Regis and wedged into rock crevices at LWN at Bembridge two days later. While in transit the animals were kept in a bucket of seawater that was changed daily. In January 1995, and at monthly intervals thereafter, one or two rock chips were taken back to the laboratory. Barnacles were removed from the rock and the basal diameter measured with callipers. For larger individuals,

Table 1. Semi-quantitative scale to describe abundance of Balanus perforatus. From Crisp \& Southward (1958).

A: Over 10 per $\mathrm{dm}^{2}$; close groups on most vertical faces, often up to MTL.

C: 1 to 10 per $\mathrm{dm}^{2}$; adjacent groups, not always above LWN.

$\mathrm{F}$ : Less than 1 per $\mathrm{dm}^{2}$; adjacent in crevices.

O: Less than 1 per $\mathrm{dm}^{2}$; rarely adjacent even in crevices.

R: Only a few found in 30 minutes' searching.

A, abundant; C, common; F, frequent; O, occasional; R, rare; $\mathrm{N}$, not found.
Table 2. Gonad condition scoring criteria for barnacles based on Crisp (1954) and O'Riordan (1992). Ovary pigmentation modified for Balanus perforatus.

\section{Male development:}

Testes

0 . Absent.

1. Poorly developed, visible only on dissection or teasing out.

2. Moderately developed, occupying a small part of the body and just visible through the cuticle, transparent to slightly white/opaque in colour.

3. Well developed, occupying much of the body cavity and clearly visible from the outside, transparent to slightly white/opaque in colour.

Vesiculae seminales

0 . Absent or present as thin strands of tissue.

1. Thin linear sacs with little sperm.

2. Moderately developed; sacs cylindrical of diameter about equal to that of the gut, clearly visible through the cuticle, opaque white in colour.

3. Well developed, sacs large and bloated exceeding diameter of gut, seminal fluid readily expelled, opaque white in colour.

\section{Female development:}

Ovary

0 . Absent, no ovary or eggs visible.

1. Poorly developed, rudimentary ovary, grey to off-white in colour, only a thin layer in the basal membrane, eggs minute, few cells, normally grey-yellow in colour.

2. Moderately developed, filling about a third of the mantle cavity, eggs multicellular, having a smooth fatty appearance, but not of full size nor completely filling the tubules, yellow in colour.

3. Well developed ovary filling the greater part of the mantle cavity, eggs with a clearly defined shape, often rounded or slightly oval, yellow in colour and filling the ovarian tubules.

the calcareous base of the shell was carefully chipped away with a scalpel to reveal gonads and any ovigerous lamellae. With the smaller animals the whole body, including gonads, ovigerous lamellae and valves, could be removed by pushing a blunt seeker into the aperture and out through the thin calcareous base. Barnacles were scored for gonad condition, and if brooding, embryonic development according to criteria in Tables $2 \& 3$. Illustrations shown in Groom (1894) were also useful.

Gonad index was plotted against number of barnacles examined to determine the minimum sample size necessary to obtain a value representative of the population. A minimum number of 20 animals was examined thereafter (Herbert, 2001). In October 1995, a further quantity of cobbles colonized with Balanus perforatus were taken from Lyme Regis to Bembridge to assess for a second year the peak percentage brooding and to determine brood size.

\section{Brood size of Balanus perforatus at Bembridge and Lyme Regis}

In mid-August 1996, ovigerous lamellae were removed from barnacles taken from Lyme Regis and those translocated from Lyme Regis to Bembridge the previous October. The embryo masses were placed in a few drops of seawater contained within a Sedgewick rafter cell to 
Table 3. Stages of barnacle embryonic development after Achituv \& Barnes (1976).

1. Early development from newly laid to few cells.

2. Multicellular.

3. Limb buds appear.

4. Nauplius eye present.

4h. Nauplii hatch on disturbance of mantle cavity.

which was then added a drop of concentrated hypochlorite to break the retaining membrane and release the embryos. The hypochlorite was neutralized by a few drops of sodium thiosulpate solution. The number of embryos within the brood was then counted under a stereo binocular microscope, sub-sampling where necessary. The basal diameter of each barnacle was measured and the somatic tissue, excluding adductor muscle, was retained and temporarily preserved in $70 \%$ denatured ethanol. The somatic tissue samples were then dried in an oven for 72 hours at $80^{\circ} \mathrm{C}$ before weighing. Dry weights were correlated with basal diameter and number of embryos the barnacles contained. The brood size for a 'standard barnacle' of $3 \mathrm{mg}$ dry weight was determined graphically using a Type 1 linear regression model.

\section{Number of broods}

The number of broods produced was determined by applying the formula of Burrows et al., (1992) for Chthamalus montagui:

$\mathcal{N}_{B}=L_{B} / L_{E}$

where $\mathcal{N}_{B}$ is the number of broods released; $L_{B}$ is the effective length of time that an individual spends carrying embryos and $L_{E}$ is the time for complete development of embryos from oviposition to release. The effective length of time that an individual spends carrying embryos $L_{B}$ is given as (Burrows et al., 1992, eqn 2):

$L_{B}=\Sigma P_{B} \times \Delta t$

where $P_{B}$ is the average proportion of the population with embryos over the brooding season and $\Delta t$ is the time interval between successive samples.

\section{RESULTS}

\section{Survey}

On the south coast of England, Balanus perforatus was 'abundant' intertidally beneath overhangs and in rock crevices within Lyme Bay and around Portland Bill (Figure 1). At two locations in Torbay it was 'abundant' on the open shore immediately below the Semibalanus balanoides zone at LWN, and beneath overhangs. Further east, along the Dorset coast, it was mainly found in crevices and beneath overhangs. Yet in May 1997 an inspection of $100-y$-old wooden piles, removed during the restoration of Swanage Pier, revealed that the species was 'abundant' (maximum 34 per $\mathrm{dm}^{2}$ ) below LWN and at densities much greater than on the shore. The zone was $1.8 \mathrm{~m}$ wide and extended into the sublittoral, where it was mixed with Balanus crenatus. On the Isle of Wight, occasional adjacent groups were found among rock boulders at the northern end of Alum Bay. In 1993 it was present on most shores along the south coast of the Isle of Wight and was most numerous at the eastern end of Reeth Bay near St Catherine's Point. At Bembridge, only a few individuals were found around the lifeboat station. The previous most easterly records of the species in the Channel are from Chichester Harbour where adults were seen on submerged test panels during the early 1960s (Stubbings \& Houghton, 1964). It was therefore particularly interesting to discover four adults on the western sides of piles on Worthing Pier in September 1994, amongst dense $S$. balanoides between mean tide level (MTL) and LWN. Five years later, in September 1999, the population had increased and the species could at least be regarded as 'frequent' and hence was in sufficient density for cross-fertilization. On some piles, adult density exceeded 10 per $\mathrm{dm}^{2}$ and there was evidence of new recruitment, with spat densities of up to 16 per $25 \mathrm{~cm}^{2}$ quadrat. A single adult specimen was also found near Cow Gap at Eastbourne. In September 2001 fewer adults could be found at Worthing, however the species was 'occasional' on the pier at Eastbourne. A single small individual was seen on the shore further east at Bexhill-on-Sea and several large adult individuals were observed on Hastings Pier. The known range of this species has therefore been extended eastward by about $120 \mathrm{~km}$. Yet the abundance at some locations further west, notably around the Isle of Wight, was not greater than found in the earlier surveys during the warm 1950s, prior to the cold winter of 1962-1963. On the French coast, the species was generally 'frequent' on granite shores along the north-west side of the Contentin Pensinsula and became common eastwards towards Barfleur, where adjacent individuals were seen at densities up to 10 per $\mathrm{dm}^{2}$ at LWN. At St Vaast, large animals were present on the open rock boulders at densities of up to 60 per $\mathrm{dm}^{2}$. Further east at Port en Bessin, large individuals at densities up to 20 per $\mathrm{dm}^{2}$ were found on sides of reefs at MTL. On the chalk coast north of Le Havre, scattered individuals were found on the sides of boulders and in crevices as far as Le Treport. Suitable habitat occurs north to Calais, however, no specimens were found. On the French coast, the intertidal distribution of $B$. perforatus has been extended eastwards by about $190 \mathrm{~km}$.

Compared to the earliest survey (Crisp \& Southward, 1958), and using the same abundance scale, B. perforatus was more abundant at 18 sites in the 1990s; at three sites it was more common in the $1950 \mathrm{~s}$; and at 17 sites there was no difference in abundance category. Ignoring sites with tied values (an effect of the broad categories used in the abundance scale, Table 1) and applying a conservative sign test, these differences are highly significant $(P=0.02$, 2 tail).

\section{Population structure}

Figure 2 gives size-frequency histograms for the populations on Broad Ledge at Lyme Regis, Warden Ledge between Colwell and Totland, and Reeth Bay near St Catherine's Point on the Isle of Wight. Young recruits appear on the Lyme Regis histogram since the site was observed in the autumn but not at the other sites surveyed in the spring. However, no recruitment was seen at the Isle of Wight sites during the autumn. 

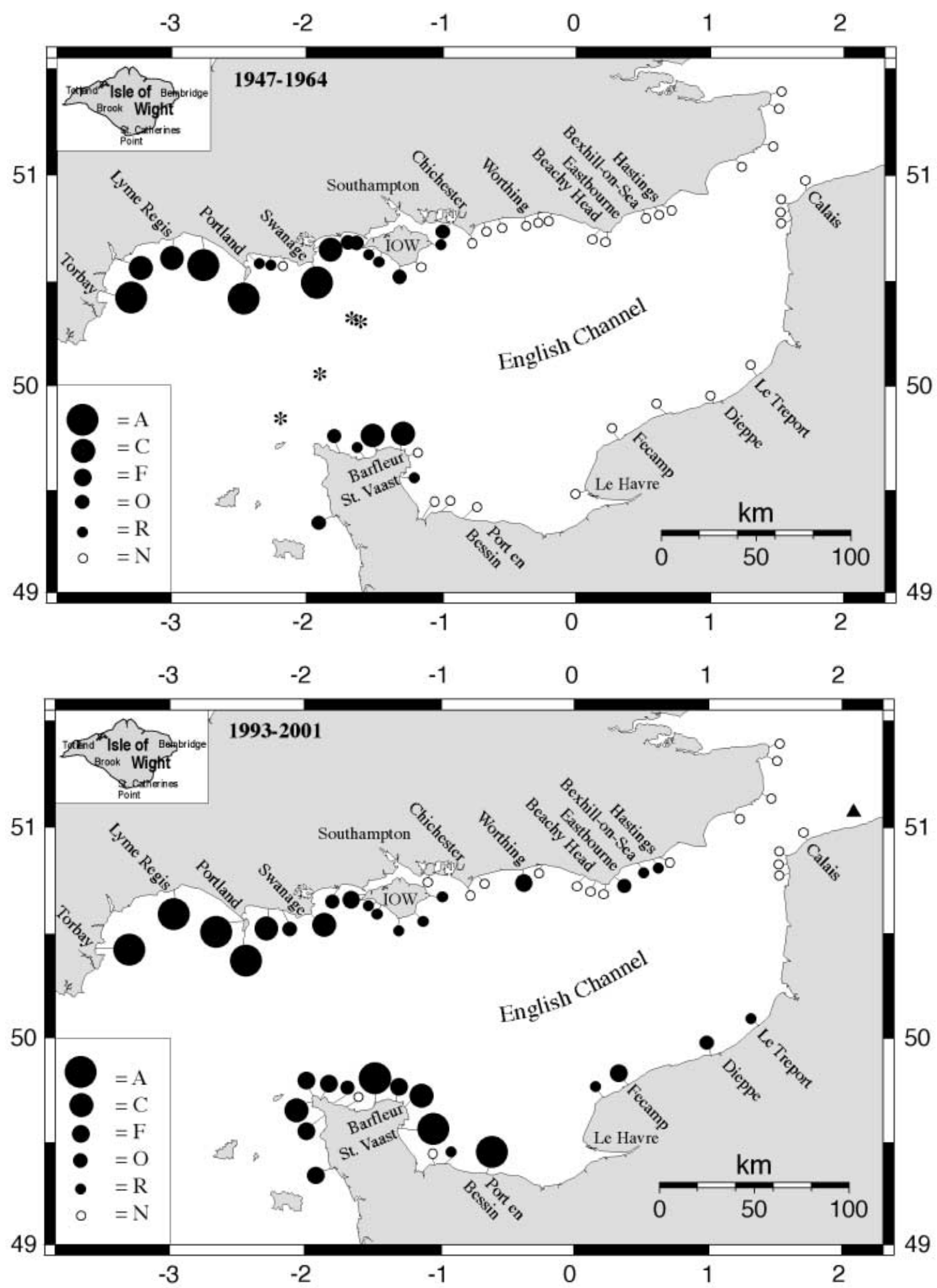

Figure 1. Distribution of Balanus perforatus in the eastern English Channel, excluding Channel Islands. Above, maximum abundance measured between 1947-1964 (Crisp \& Southward, 1958; A.J.S., personal observation). For abundance scale see Table 1. *, denotes records from the SV 'Manihine' (BMNH collection). Below, intertidal distribution between 1993-2001. Black triangle indicates sublittoral record from Dunkirk in 1982 (Davoult et al., 1993).

Reproduction of translocated specimens at Bembridge, Isle of Wight

Larger numbers (maximum 31) of living specimens were examined in the months May-October, when brooding was most likely. Fully ripe ovaries were not seen until July, when they were present in 5\% of the sample (Figure 3). A single specimen with Stage 2 embryos was found on 20 May 1995, earlier than previously recorded in British waters. Stage 3 ovaries were observed until October, reaching a maximum in September $(40 \%)$. The opaque 


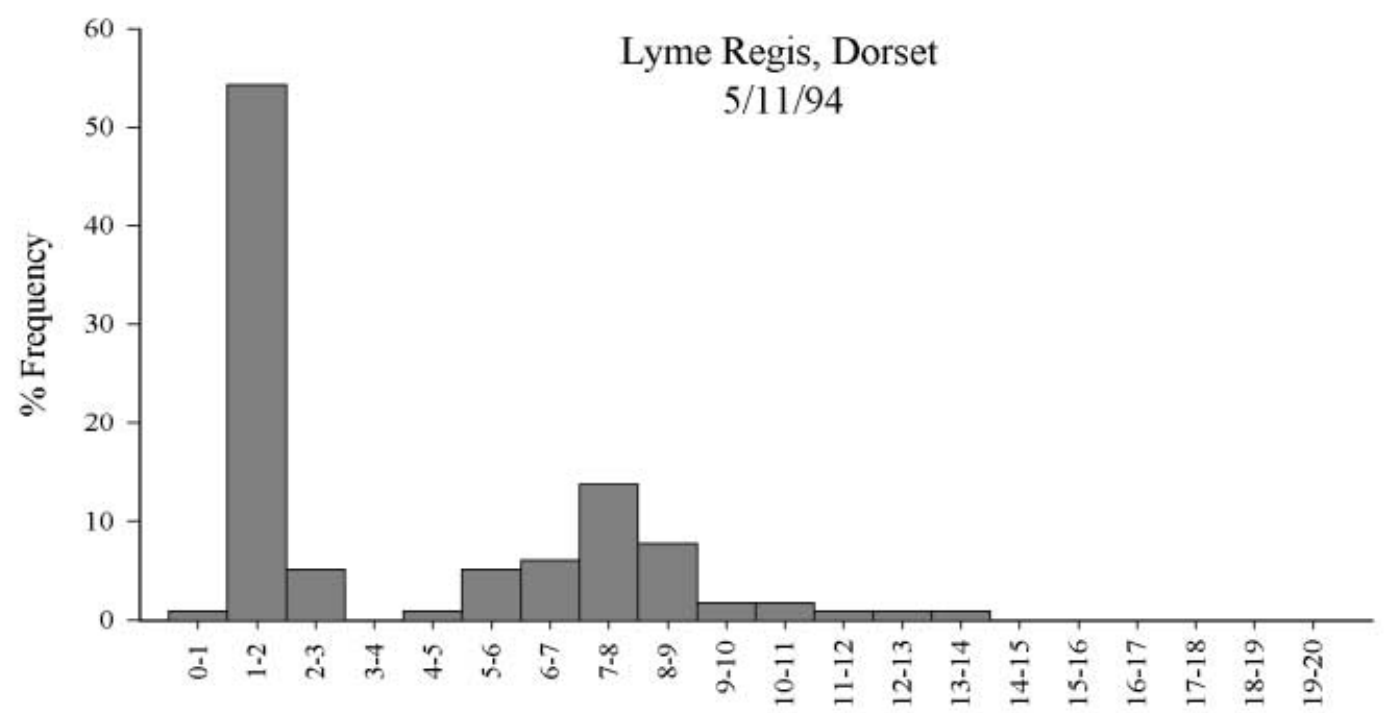

Basal Diameter (mm)

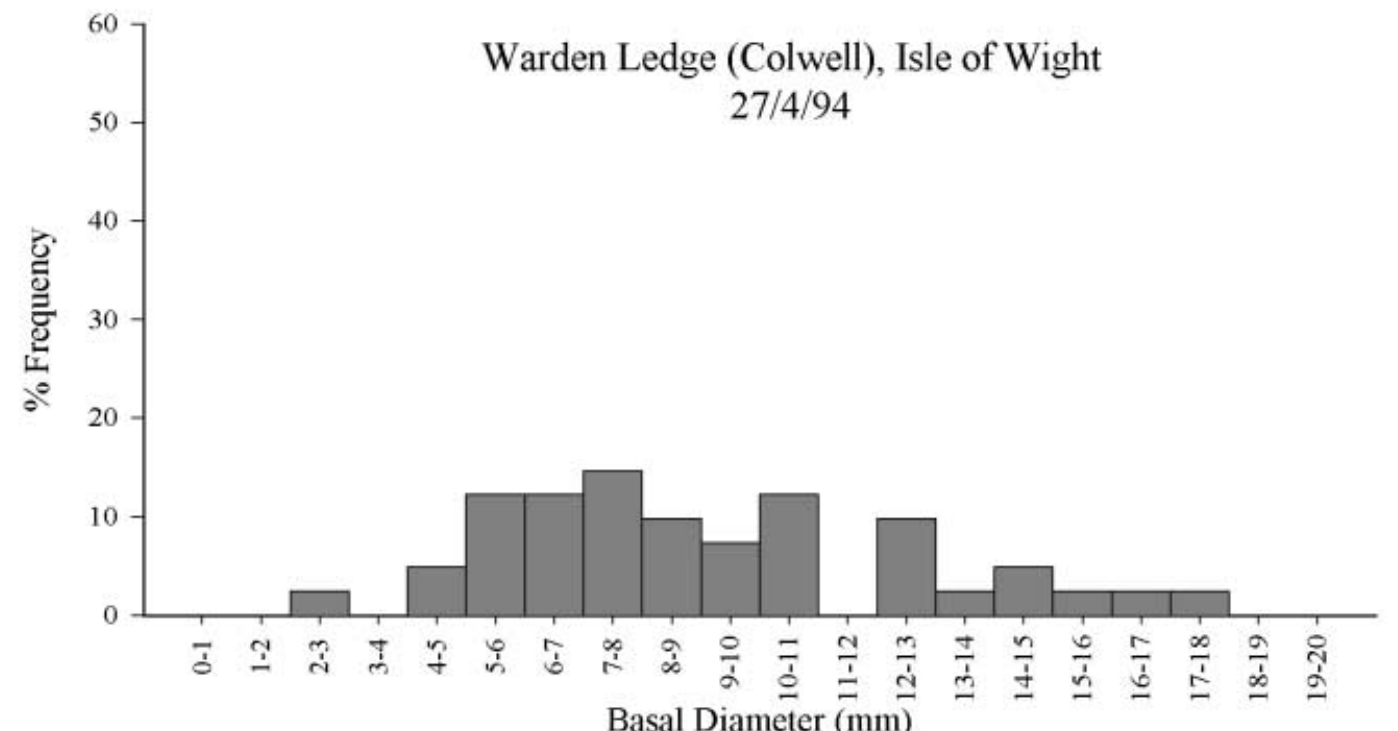

Basal Diameter (mm)

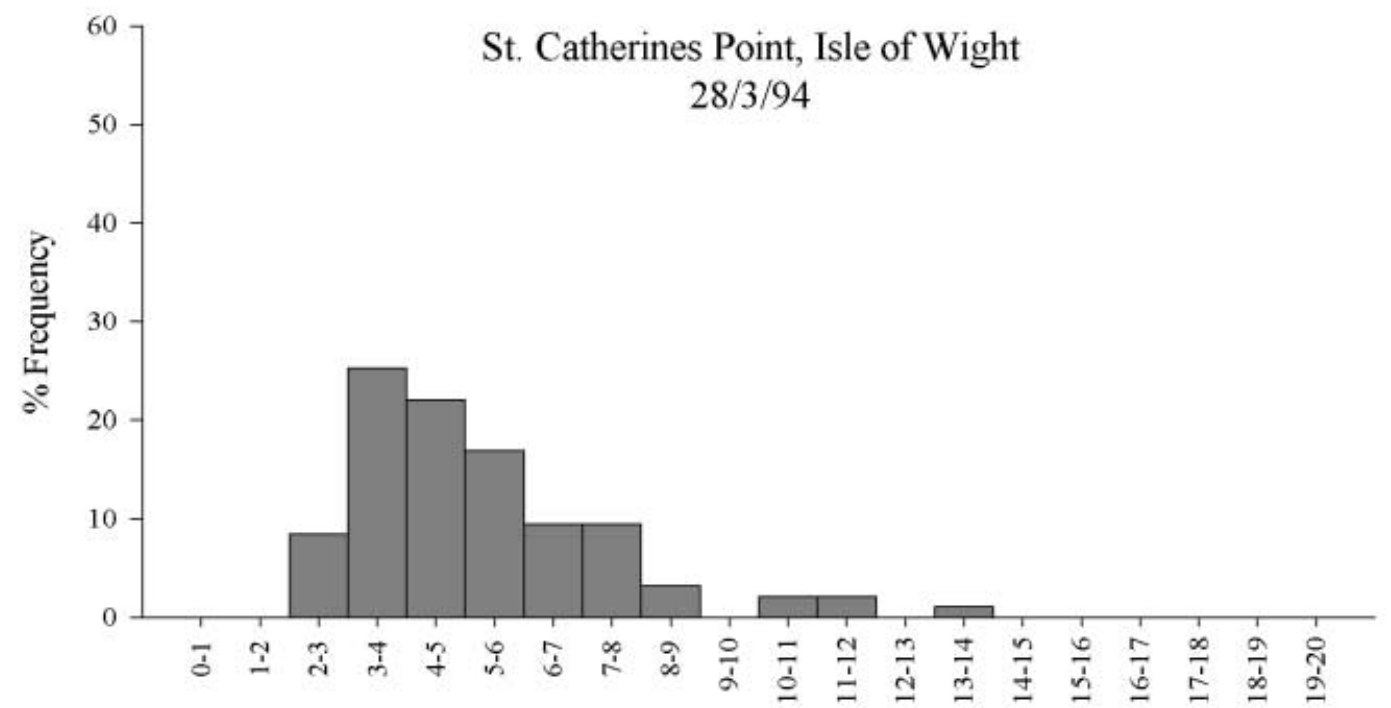

Basal Diameter (mm)

Figure 2. Population size-frequency histograms of Balanus perforatus at shores approaching eastern Channel limits. Lyme Regis, $\mathrm{N}=116$; Colwell, $\mathrm{N}=41$; St Catherine's Point, $\mathrm{N}=95$. 

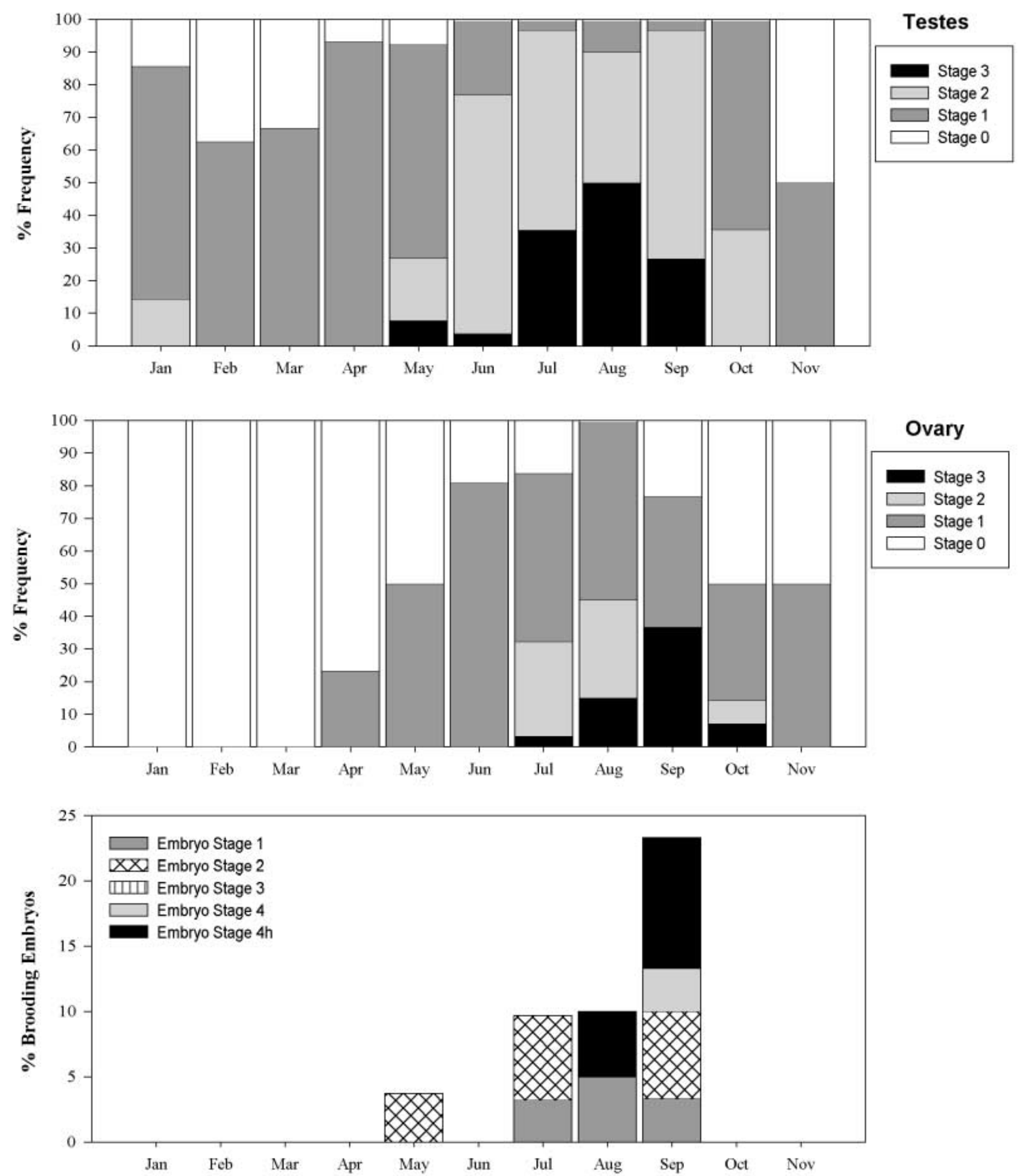

Figure 3. Seasonal development of gonads and embryos in translocated Balanus perforatus at Bembridge, Isle of Wight, between January and November 1995.

male gonads appeared to develop earlier than the ovaries with Stage 3 testes present between May and September, peaking at $50 \%$ in August. Stage 3 vesiculae seminales were present between May and October, with a maximum in August. The intensity of yellow pigmentation increased as the eggs and ovarian tissue developed. Brooding was first observed in May, but no more were seen until July when they were present in almost $10 \%$ of the sample. Embryos at hatching stage (Stage 4h) were seen in August and September, when they comprised $50 \%$ and $40 \%$ respectively of those individuals brooding. The maximum brooding embryos was $23 \%$, on 15 September, although none were seen thereafter. An isolated individual examined in September had Stage 4h embryos; an observation consistent with the known ability of the species to undergo self-fertilization (Barnes \& Crisp, 1956). 


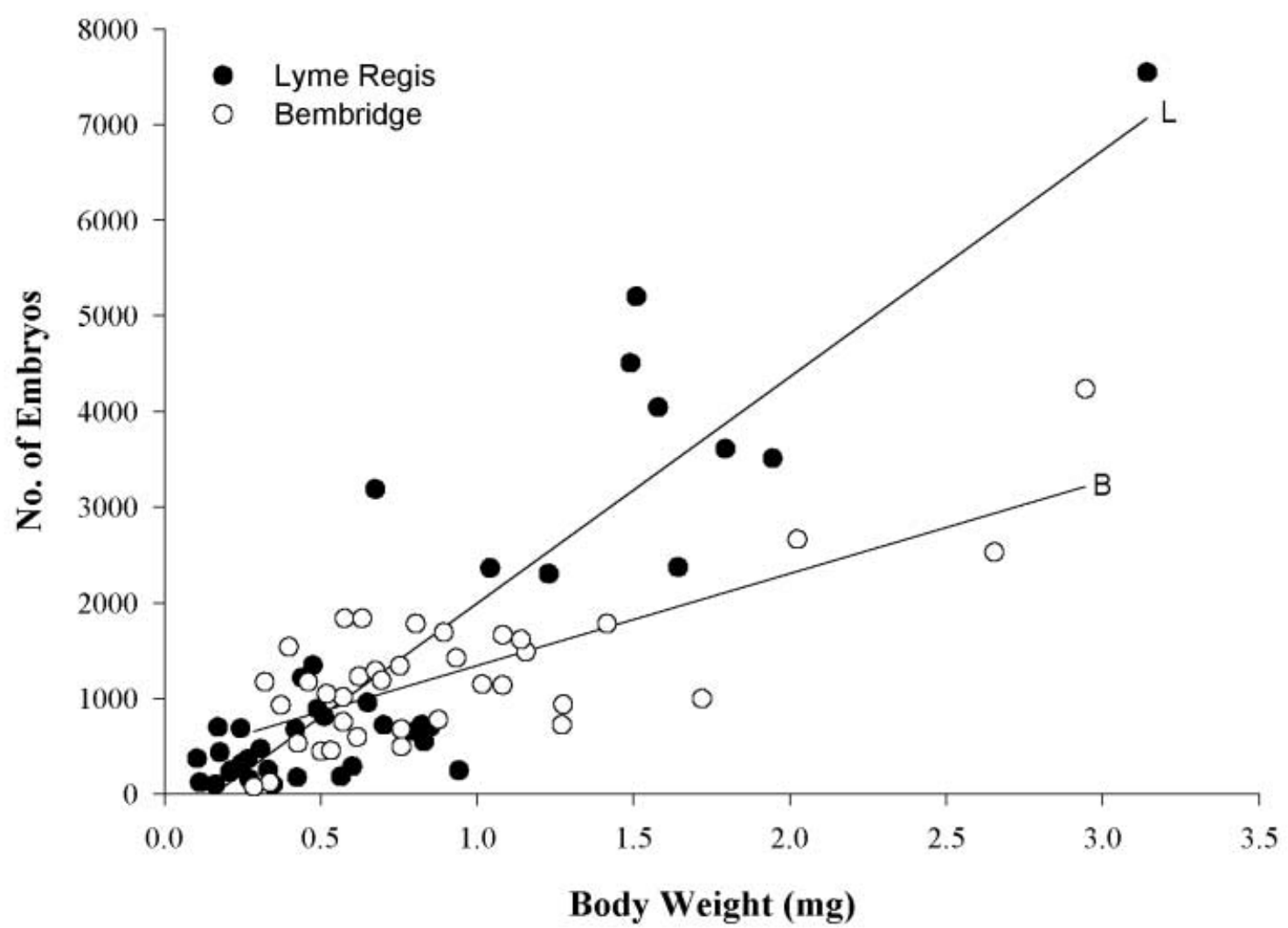

Figure 4. Relationship between brood size and body weight of Balanus perforatus at Lyme Regis and those translocated to Bembridge, Isle of Wight, in October 1995. Animals sampled from LWN in August 1996. Type 1 linear regression line shown: Lyme Regis $(\mathrm{L}), y=2637.8 \mathrm{x}-372.3, \mathrm{~N}=39, r^{2}=0.80, F=146.5, P<0.0001$. Bembridge $(\mathrm{B}), y=964.5 \mathrm{x}+378.6, \mathrm{~N}=37, r^{2}=0.57$, $F=46, P=<0.0001)$.

Stage of reproductive development at Bembridge and Lyme Regis in August 1996

Five of the rocks translocated from Lyme Regis to Bembridge were removed from the shore on 22 August 1996. Each of four rocks were treated as separate samples and the percentage brooding embryos varied between $12 \%$ and $47 \%$ (mean $27.3 \%, N=4$ ). Of the 31 with broods, plus an additional 16 removed from the fifth rock, $45 \%$ were at Stage 4 and $30 \%$ at the hatching stage. Three broods had a single lamella. At Lyme Regis, the percentage of the population brooding embryos was much higher, varying between $62 \%$ and $74 \%$ (mean $66 \%$, $\mathrm{N}=64$ ). Of those with embryos, $32 \%$ were at Stage 4 and $39 \%$ at the hatching stage. At Bembridge, brooding barnacles were found with Stage 1 ovaries only, but at Lyme Regis $17 \%$ of those with embryos had ovaries at Stage 2. Yet there was no significant difference in the frequency of the embryonic stages (KolmogorovSmirnov test $\mathrm{N}=44, \quad 47$; maximum $\mathrm{D}=0.071$; $P>0.95$ n.s.). A Spearman rank test, applied to determine whether there was a correlation between embryonic and ovarian development, showed no significant relationship at either of the two sites. (Lyme Regis: $\mathrm{N}=43, \mathrm{r}_{\mathrm{s}}=0.112$, $P=0.47$; Bembridge: $\left.\mathrm{N}=30, \mathrm{r}_{\mathrm{s}}=0.054, P=0.77\right)$. Thus there is little empirical evidence for regeneration of ovaries and a succession of broods within the populations of $B$. perforatus studied.

\section{Brood size of Balanus perforatus at Bembridge and Lyme Regis}

Linear regression equations of body weight against R-C diameter were highly significant $(P<0.0001)$ from both sites (Lyme Regis: body weight $=0.156 \mathrm{mg} \mathrm{mm}^{-1} \times \mathrm{R}-\mathrm{C}$ $-0.894 \mathrm{~mm}$; Bembridge: body weight $=0.165 \mathrm{mg} \mathrm{mm}^{-1} \times$ R-C $-0.795 \mathrm{~mm})$. There was no significant difference between the slopes of regression lines of body weight against R-C diameter of the two samples $(t=0.23, \mathrm{df}=82$, $P>0.1$ n.s.).

Animals from Lyme Regis had broods of between 104 and 7550 embryos and body weight between 0.1 and $3.14 \mathrm{mg}$ (Figure 4). Broods were observed in animals with a basal diameter as small as $5.7 \mathrm{~mm}$ (Figure 5). The translocated sample at Bembridge had a similar size range with body weight between $0.2-2.9 \mathrm{mg}$. Brood size varied between 80-4242 embryos and ovigerous lamellae were seen in the smallest animal in the sample of basal diameter $6.8 \mathrm{~mm}$ (Figure 5). Linear regression equations of brood size against body weight for both sites were very highly significant $(P<0.0001)$. Barnes \& Barnes $(1968)$ gave a brood size of 7250 for a 'standard barnacle' of body weight $3 \mathrm{mg}$ from the French coast. From the regression equations for Lyme Regis and Bembridge, brood sizes for a 'standard barnacle' are 6730 and 3270 embryos respectively. An analysis of covariance (ANCOVA) found there to be a significant difference in brood size between sites using body weight as a covariate (Table 4). 


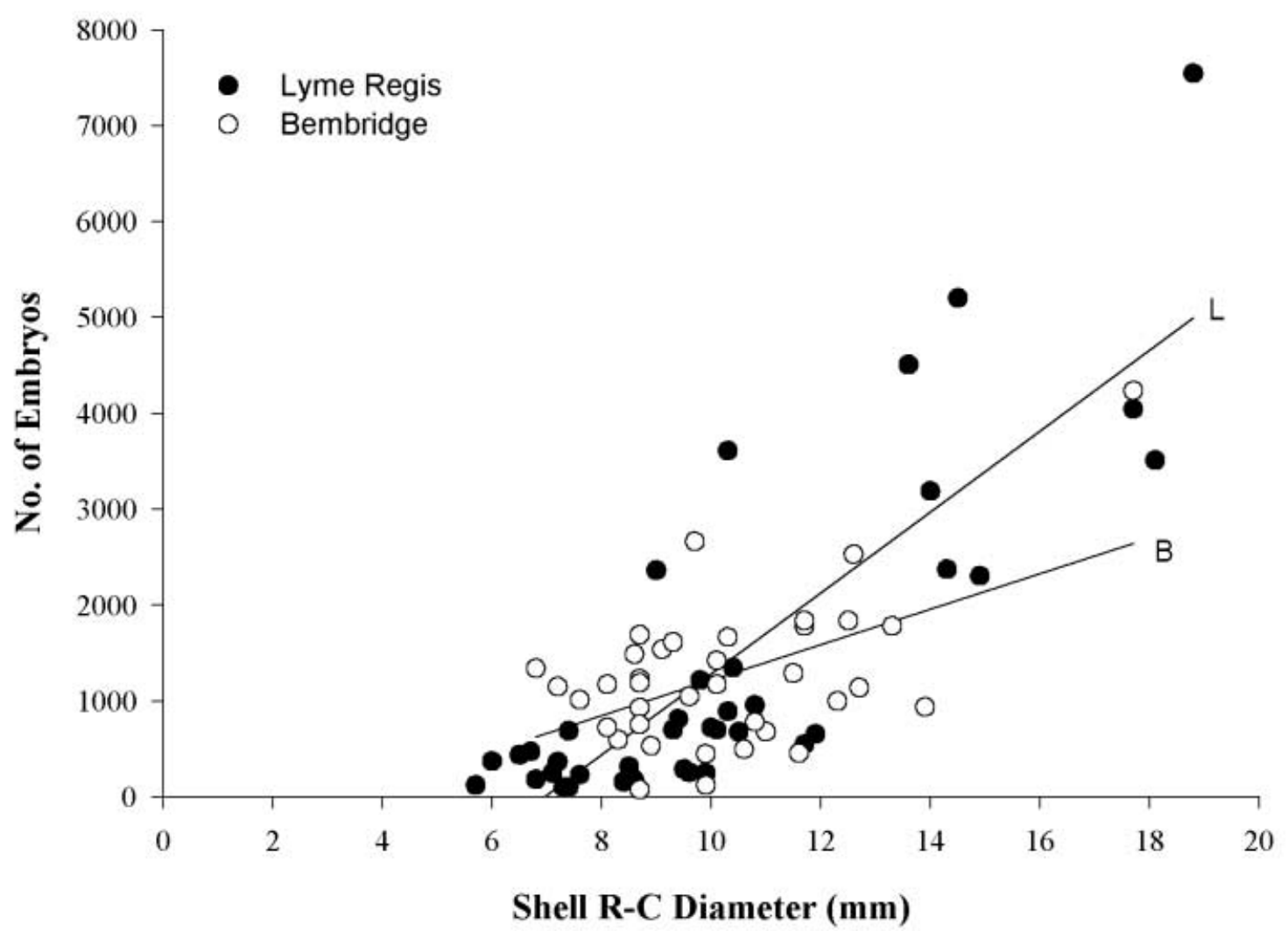

Figure 5. Relationship between brood size and basal diameter (R-C axis) of Balanus perforatus at Lyme Regis and those translocated to Bembridge, Isle of Wight, in October 1995. Animals sampled from LWN in August 1996. Type 1 linear regression line shown: Lyme Regis (L), $y=421.7 \mathrm{x}-2935.1, \mathrm{~N}=44, r^{2}=0.68, F=75.7, P<0.0001$. Bembridge $(\mathrm{B}), y=185 \mathrm{x}-632.3, \mathrm{~N}=38$, $\left.r^{2}=0.27, F=13.1, P=0.0009\right)$.

Table 4. ANCOVA of Balanus perforatus brood size from Lyme Regis and sample translocated to Bembridge. ' $N$ o. of eggs' being the dependent variable, 'Shores' the main effect and 'Body weight' the covariant. The effect of body weight as a covariate is highly significant, and there is also a significant difference in brood size between shores.

\begin{tabular}{|c|c|c|c|c|}
\hline Source of variation & $\mathrm{df}$ & MS & $F$ & $P$ \\
\hline Body weight & 1 & 86235733 & 138.20 & $<0.0001 * * *$ \\
\hline Shore & 1 & 3206896.8 & 5.14 & $0.026^{*}$ \\
\hline Residual & 73 & 624127.4 & & \\
\hline Total & 75 & & & \\
\hline
\end{tabular}

\section{Number of broods}

Patel \& Crisp (1960b) found that in vitro, the species has a rapid rate of embryonic development; at $14.5^{\circ} \mathrm{C}$ it was 6 days and at $20^{\circ} \mathrm{C}$ as short as 4 days.

Theoretically therefore, despite late summer brooding, there is plenty of time available for several broods. Using the methods of Burrows et al. (1992) described above, the estimated number of broods for the animals translocated to Bembridge and sampled monthly in 1995 are:

$\mathcal{N}_{B}=L_{B} / L_{E}=14 / 6=2.3$ Broods per year at $14.5^{\circ} \mathrm{C}$

$=14 / 4=3.5$ Broods per year at $20.0^{\circ} \mathrm{C}$

\section{DISGUSSION}

On both sides of the Channel, Balanus perforatus now occurs intertidally from 120 to $190 \mathrm{~km}$ east of previously known limits. On the south coast of England, however, the distribution is not continuous. Although present on pier piles, the species was surprisingly absent from nearby rocky platforms and boulder shores. The chalk shores along this coast were initially considered to be too soft for satisfactory adhesion, yet the species is common on the sides of chalk boulders at Beer in Devon; and on the French coast, scattered individuals were found on chalk boulders north of Le Havre. It is possible that successful larval development and settlement is dependent on a degree of thermal stratification within the water column that is more likely within sheltered bays than near rocky headlands. This may account for the observations of the species on piers, built on sandy beaches within the relatively embayed coasts either side of the exposed rocky promontory of Beachy Head. The presence of artificial substrates, including piers, and the increasing number of breakwaters, marinas and sea defences may have facilitated recent colonization along this coast. The future rate of population growth could therefore accelerate beyond 
that which might occur as a result of climatic changes alone. There is no doubt that had these eastern intertidal populations existed prior to the severe winter 1962-1963 they would have been killed, along with those on the Isle of Wight and much of Dorset. Considering the relatively low densities that currently exist on these eastern shores, it is possible that re-colonization or new colonization might have been aided by recruitment from sublittoral populations in deeper water that survived the severe cold. Between 1947-1949, the converted trawler 'Manihine' collected specimens south of the Isle of Wight at 36-73 m depth (Figure 1). To our knowledge, recent sublittoral surveys have failed to locate $B$. perforatus along the southeast coast of England: however, identification may be a problem with possible individuals, often encrusted with epibiota, referred to as Balanus sp.

There are few records for the Channel Islands, situated in a more sheltered position with regard to the cold southeast winds of the 1962-1963 winter. However, surveys by one of us (A.J.S.) in 1976 showed that since 1956 Balanus perforatus abundance had changed little in Jersey and on the south coast of Guernsey, but may have declined along the north coast of Guernsey.

For the experiments on reproduction, it was not possible to fix broken rocks to the shore at Lyme Regis in the same manner as those translocated to Bembridge and the experimental procedure lacks a control for physical disturbance. However, there is no reason to doubt the species ability to breed normally on eastern shores; brooding of specimens translocated to Bembridge was recorded in mid-May, the earliest so far observed in British waters. In south-west England it is known to breed during the summer months (Norris \& Crisp, 1954; Patel \& Crisp, 1960a,b) and this was also apparent at Bembridge, with brooding continuing until mid-September. In laboratory experiments, Patel \& Crisp (1960b) found that the species did not commence brooding until the water temperature was $15{ }^{\circ} \mathrm{C}$, when $5 \%$ of the sample were observed with embryos; this rose to $60 \%$ at a temperature of $19{ }^{\circ} \mathrm{C}$. In May 1995 the sea temperature measured from the shore at Bembridge was unusually high at $18.5^{\circ} \mathrm{C}$ and would be expected to favour reproduction. It is significant that no broods were observed in June when the inshore temperature dropped back to $15.5^{\circ} \mathrm{C}$. For Torbay, Norris \& Crisp (1953) mention that egg masses rarely occur before mid-June although Burrows (1988) observed Stage IV nauplii near Plymouth in early June 1984. At Naples, in the Mediterranean, brooding occurs in April (Lochhead, 1936), but becomes less common later in the season, suggesting that higher temperatures may limit production or there is insufficient food. The samples taken from Lyme Regis in August 1996 had much higher proportions brooding than those translocated to Bembridge; similar to observations of $66 \%$ in North Devon by Barnes \& Crisp (1956).

Multiple brooding at the observed sea temperatures, though theoretically possible, remains unconfirmed in the Channel, though Stage 1 and 2 ovaries had developed while embryos were present. Through serial sampling of a population from the Gower peninsula in Swansea, South Wales, Patel \& Crisp (1960a) suggested that Balanus perforatus probably had more than one brood annually. At Plymouth, Burrows (1988) considered that the sudden increases in abundance of Stage II nauplii observed in late July/August and September might result from two synchronized releases per year. In the Mediterranean, Lepore et al. (1979) found that animals which had a minimum basal diameter of $1 \mathrm{~cm}$ contained mature gonads throughout the year, although multiple broods were unconfirmed; the major brood release was in August and maximum settlement in September. At Arcachon, Barnes \& Klepal (1971) suggested that the species does have multiple broods and that the spermatozoa mature while the eggs of one brood are developing and the ova of the next are being produced.

Compared to south-west England, inshore summer temperatures in the eastern Channel are higher, so the breeding season ought to be longer. However the survival and growth of nauplii is likely to be dependent on food availability as well as temperature.

The brood size of B. perforatus has never been fully investigated. Barnes \& Barnes (1968) provide a figure of 7250 eggs for an animal of $3 \mathrm{mg}$ body weight from Arcachon. We have determined comparable values of 6730 from Lyme Regis and 3720 embryos from translocated specimens at Bembridge. Again, the within-site variance needs to be fully investigated before any conclusions are drawn. The smaller brood size at Bembridge might have been caused by impaired feeding following the physical disturbance.

It is proposed that the observed range extension is due to more frequent and multiple brooding. Strong offshore currents must reduce larval supply to the shore and the rate of progression eastwards along the Channel. The greater range expansion on the French coast may result from more favourable substrata and less larval loss. Careful and more frequent surveys combined with studies of settlement and recruitment will help to elucidate the importance of these and other variables. It is likely that range extension can be induced by a series of warm summers, such as happened in the 1990s. Extreme cold weather, as in 1962 and 1963 can trim back ranges, with subsequent recovery taking many years.

Thanks to Professor G. Boxshall of the British Museum of Natural History for access to the 'Manihine' specimens. We acknowledge support from NERC grant GR9/02390 (to S.J.H. and A.J.S.) and the MarClim Consortium (EN, EA SNH, WWF, CCW, States of Jersey, Scottish Executive, DEFRA, Crown Estates). S.J.H. was also supported by the EU 'Delos' project.

\section{REFERENCES}

Achituv, Y. \& Barnes, H., 1976. Studies in the biochemistry of cirripede eggs. V. Changes in the general biochemical composition during development of Chthamalus stellatus (Poli). Fournal of Experimental Marine Biology and Ecology, 22, 263-267.

Barnes, H. \& Barnes, M., 1968. Egg numbers, metabolic efficiency of egg production and fecundity; local and regional variations in a number of common cirripedes. Fournal of Experimental Marine Biology and Ecology, 2, 135-153.

Barnes, H. \& Crisp, D.J., 1956. Evidence of self-fertilization in certain species of barnacles. Fournal of the Marine Biological Association of the United Kingdom, 35, 631-639.

Barnes, H. \& Klepal, W., 1971. Observations on the form and changes in the accessory droplet and motility of the spermatozoa of some cirripedes. Fournal of Experimental Marine Biology and Ecology, 7, 173-196. 
Burrows, M.T., 1988. The comparative biology of Chthamalus stellatus (Poli) and Chthamalus montagui Southward. PhD thesis, University of Manchester.

Burrows, M.T., Hawkins, S.J. \& Southward, A.J., 1992. A comparison of reproduction in co-occurring chthamalid barnacles Chthamalus stellatus (Poli) and Chthamalus montagui Southward. Fournal of Experimental Marine Biology and Ecology, 160, 229-249.

Buizer, D.A.G., 1978, First autochthonous records of Balanus perforatus Bruguière (Cirripedia, Balanomorpha) and Conchoderma auritum (L.) (Cirripedia, Lepadomorpha) in coastal waters of the Netherlands. Zoologische Bijdragen, 23, 34-37.

Crisp, D.J. 1954. The breeding of Balanus porcatus (Da Costa) in the Irish Sea. Fournal of the Marine Biological Association of the United Kingdom, 33, 473-496.

Crisp, D.J., ed., 1964. The effects of the severe winter of 19621963 on marine life in Britain. Fournal of Animal Ecology, 33, $165-210$.

Crisp, D.J. \& Southward, A.J., 1953. Isolation of intertidal animals by sea barriers. Nature, London, 172, 208-209.

Crisp, D.J. \& Southward, A.J., 1958. The distribution of intertidal organisms along the coasts of the English Channel. Fournal of the Marine Biological Association of the United Kingdom, 37, 157-208.

Davoult, D., Dewarumez, J.-M. \& Glaçon, R., 1993. New additions to macrobenthic species from the French coasts of the eastern English Channel and North Sea (4): Miscellaneous groups. Cahiers de Biologie Marine, 34, 55-64.

Fischer-Piette, E., 1936. Etudes sur la biogéographie intercotidale des deux rives de la Manche. Fournal of the Linnean Society. Zoology, 40, 181-272.

Groom, T.T., 1894. On the early development of the Cirripedia. Philosophical Transactions of the Royal Society B, 185, 119-212.
Herbert, R.J.H., 2001. Testing hypotheses related to changes in abundance and distribution of warm-temperate invertebrates on rocky shores along the south coast of England. $\mathrm{PhD}$ thesis, University of Southampton.

Kerckhof, F. \& Cattrijsse, A., 2001. Exotic Cirripedia (Balanomorpha) from buoys off the Belgian coast. Senckenbergiana Maritima, 31, 245-254.

Lepore, E., Sciscioli, M. \& Gherardi, M., 1979. Observations on the oogenesis and spermatogenesis in some cirripedes. Memorie di Biologia Marina e di Oceanografia, 9(5), 115-122.

Lewis, J.R., 1964. The ecology of rocky shores. Hodder \& Stoughton.

Lochhead, J.H., 1936. On the feeding mechanism of the nauplius of Balanus perforatus Bruguière. Proceedings of the Linnean Society of London (Zoology), 39, 429-442.

Norris, E. \& Crisp, D.J., 1953. The distribution and planktonic stages of the cirripede Balanus perforatus Bruguière. Proceedings of the Linnean Society of London (Zoology), 123, 393-409.

O'Riordan, R., 1992. Reproduction and recruitment of two intertidal Chthamalid barnacles. PhD thesis. University College Cork, Eire.

Patel, B. \& Crisp, D.J., 1960a. Rates of development of the embryos of several species of barnacles. Physiological Zoology, 33, 104-119.

Patel, B. \& Crisp, D.J., 1960b. The influence of temperature on the breeding and the moulting activities of some warm-water species of operculate barnacles. Fournal of the Marine Biological Association of the United Kingdom, 39, 667-680.

Pelseneer, P., 1882. Etudes sur la fauna littorale de la Belgique. Bulletin des Séances. Annales de la Société Royale Malacologique de Belgie, 17, 31-43.

Stubbings, H.G. \& Houghton, D.R., 1964. The ecology of Chichester Harbour southern England, with special reference to some fouling species. International Revue der Gesamt Hydrobiologie, 49, 233-279.

Submitted 21 May 2002. Accepted 26 November 2002. 